\title{
Corrigendum: In utero therapy for congenital disorders using amniotic fluid stem cells
}

\author{
Durrgah L. Ramachandra ${ }^{1}$, Sheng-Wen Steven Shaw ${ }^{2,3,4}{ }^{*}$, Panicos Shangaris ${ }^{4}$, \\ Stavros Loukogeorgakis ${ }^{1}$, Pascale V. Guillot ${ }^{1,5}$, Paolo De Coppi ${ }^{1}$ and Anna L. David ${ }^{4}$ \\ ${ }^{1}$ Stem Cells and Regenerative Medicine, Institute of Child Health, University College London, London, UK \\ 2 Department of Obstetrics and Gynaecology, Chang Gung Memorial Hospital at Linkou, Taoyuan, Taiwan \\ ${ }^{3}$ Department of Obstetrics and Gynaecology, College of Medicine, Chang Gung University, Taoyuan, Taiwan \\ ${ }_{4}^{4}$ Prenatal Therapy, Institute for Women's Health, University College London, London, UK \\ ${ }^{5}$ Cellular Reprogramming and Perinatal Therapy, Institute for Women's Health, University College London, London, UK \\ *Correspondence: dr.shaw@me.com \\ Edited and reviewed by: \\ Graca Almeida-Porada, Institute for Regenerative Medicine, USA
}

Keywords: amniotic fluid, stem cell, transplantation, prenatal, cell therapy

\section{A corrigendum on}

In utero therapy for congenital disorders using amniotic fluid stem cells

by Ramachandra, D. L., Shaw, S. S. W., Shangaris, P., Loukogeorgakis, S., Guillot, P. V., De Coppi, P., and David, A. L. (2014). Front. Pharmacol. 5:270. doi: 10.3389/fphar.2014.00270

I am writing this manuscript to correct the second author information. My name is correctly spelt, S.W. Steven Shaw. But "S.W. Steven" is the first name, "Shaw" is the last name. My publications are always searched by "Shaw SW" in pubmed. However, in this article, my name is searched by "Shaw SS."

Conflict of Interest Statement: The authors declare that the research was conducted in the absence of any commercial or financial relationships that could be construed as a potential conflict of interest.

Received: 30 January 2015; accepted: 12 February 2015; published online: 03 March 2015.

Citation: Ramachandra DL, Shaw SWS, Shangaris $P$, Loukogeorgakis S, Guillot PV, De Coppi P and David
AL (2015) Corrigendum: In utero therapy for congenital disorders using amniotic fluid stem cells. Front. Pharmacol. 6:39. doi: 10.3389/fphar.2015.00039 This article was submitted to Integrative and Regenerative Pharmacology, a section of the journal Frontiers in Pharmacology.

Copyright (ㅇ 2015 Ramachandra, Shaw, Shangaris, Loukogeorgakis, Guillot, De Coppi and David. This is an open-access article distributed under the terms of the Creative Commons Attribution License (CC BY). The use, distribution or reproduction in other forums is permitted, provided the original author(s) or licensor are credited and that the original publication in this journal is cited, in accordance with accepted academic practice. No use, distribution or reproduction is permitted which does not comply with these terms. 